\title{
Sources of Stress: Perceptions of South African TESOL Teachers
}

\author{
Amanda Bowen \\ Wits Business School, University of the Witwatersrand, South Africa
}

Copyright $(2016$ by authors, all rights reserved. Authors agree that this article remains permanently open access under the terms of the Creative Commons Attribution License 4.0 International License

\begin{abstract}
This paper presents the findings of a qualitative study investigating which factors inside and outside the classroom result in feelings of stress for TESOL teachers working at private language schools in South Africa. Using in-depth semi-structured interviews, the findings reveal three main areas that cause stress for TESOL teachers: the job of teaching, relationships at work and organisational and TESOL-related issues. These three areas of stress can be further divided into various sub-themes. Stress resulting from the job of teaching includes the sub-themes of work overload, inadequate training and gaps in subject knowledge, time pressure and student behaviour. Stress resulting from relationships at work includes the sub-themes of negative relationships with colleagues, administrators and management. Stress resulting from organisational and TESOL-related issues includes the sub-themes of working conditions, lack of teaching resources, shared spaces and lack of professional development and career advancement. There has not yet been an investigation into the causes of stress among South African TESOL teachers. This paper is thus an attempt at laying the foundation for further research. The results provide valuable information for TESOL teacher trainers, TESOL co-ordinators and the management of private language schools.
\end{abstract}

Keywords TESOL, EFL, ESL, English Language Teaching, TESOL Teacher Stress, Status of TESOL, Private Language Schools, South Africa

\section{Introduction}

There is growing interest in researching the teaching experience especially studies of what teachers find stressful and how they cope with stress (Golombek and Doran, 2014 [1], Horwitz, 2012 [2]). Teacher stress is ubiquitous in a wide variety of teaching contexts ranging from primary and secondary to tertiary educational institutions. The sources of stress are as varied as the educational and geographical contexts. Larrivee (2012:12) [3] defines stress as a state of anxiety produced when events and responsibilities exceed one's coping abilities or "stress is what happens when life hands you more than you can handle." Kyriacou (2001) [4] maintains that teaching is one of the top five most stressful careers while Manuel (2003, p.142) [5] describes teaching as the only profession "that eats its young." According to Friesen, Prokop and Sarros (1998, p.9) [6], the reason teaching is so stressful is because it involves "daily interactions with students and co-workers...with the incessant and fragmented demands of teaching often resulting in overwhelming pressures and challenges which lead to stress." When this stress becomes unrelenting, it can lead to negative physiological, psychological and behavioural consequences for teachers.

Maslach and Leiter (1999, p.295) [7] state that compared to other service professions, teaching is "unique in that... working relationships are dealt with en masse within a classroom unlike the more individual and sequential focus of other human services." Furthermore, although the quality of the relationship between teacher and student is often the most rewarding aspect of teaching it is also the point at which teachers "are vulnerable to emotionally draining and discouraging experiences" (Maslach et al., 1999, p.296) [7]. Recurrent themes that emerge from the literature on teacher stress include administrative overloading, ambiguous educational policies and curricula, low salaries, poor working conditions, negative relationships with colleagues and supervisors, student behavioural problems and a lack of professional development, recognition and career advancement (Chang (2009) [8], Prilleltensky, Neff \& Bessell (2016) [9], Van Tonder \& Williams (2009) [10]).

There is a considerable body of research on the prevalence of stress among primary and secondary school teachers and among academics working in higher education in South Africa (Barkhuizen, Rothmann \& Tytherleigh (2008) [11], Barkhuizen, Rothmann \& van de Vijver (2014) [12], Monareng (2006) [13], Peltzer, Shisana, Zuma, Van Wyk \& Zungu-Dirwayi (2009) [14], Olivier \& Venter (2003) [15], Shin and Jung (2014) [16]). However, there are currently no research studies which investigate the experience of teacher stress within the South African TESOL industry. 
University-affiliated and private language schools are the main employers of TESOL teachers in South Africa as there are strict entry requirements ${ }^{i}$ to the field of teaching English within the primary and secondary school system. South Africa is increasingly being viewed as a cost-effective alternative for foreign students who would, in the past, have chosen to study English in Australia, Canada, New Zealand, the UK or the USA. Thus, there are increasingly more employment opportunities for TESOL teachers in South Africa which makes research into the teaching experiences of South African TESOL teachers all the more relevant.

Johnston (1997, p. 682) [17] notes that little is known about the lives of teachers who work in the TESOL field and that "it is time to gather empirical data about the working lives of actual teachers and to make these lives the focus of research." Over nineteen years later there has not been a great deal of progress since this statement as the vast majority of TESOL research studies still focus on TESOL students, English language teaching methodologies and techniques and the English language itself while arguably, the most important people, those who teach the language have not been the focus of sustained research.

Thus, in terms of research focused on the inner lives of teachers, it appears that TESOL teachers have drifted out of the picture, "often reduced to two-dimensional figures with no character, concerns, or lives of their own" (Griffiths, 2012, p.474) [18]. Simon-Maeda (2004, p.406) [19] refers to this as "ignoring the realities of teachers' lives both inside and outside the classroom." According to Kassagby, Boraie \& Schmidt (2001, p.227) [20], there is little information about what "makes English language teachers tick - their motivations, goals and their views on what teaching does and should offer to people who make a career of it."

All around the world TESOL teachers express not only great satisfaction with, but also deep dissatisfaction about their work. Among the satisfactions commonly voiced about a career in TESOL are the opportunities for travelling the world, interactions with people of different cultures, and the chance to teach the English language in creative and exciting ways (Kim \& Kim, 2015) [21]. At the same time, there is much dissatisfaction among TESOL teachers ranging from complaints about low salaries and the almost universal lack of benefits to inadequate recognition on, and of the job, coupled with chronic job insecurity and in some cases, gross exploitation (Walker, 2014) [22]. Sun (2010, p.142) [23] maintains that TESOL teachers are generally "disenchanted with their working conditions" and deeply concerned about inequitable workloads, undesirable working conditions, low pay, job insecurity and a lack of professional development and support.

A survey of the literature on the professional status of TESOL teachers reveals that they lack the social standing granted to other professions (Crandall \& Christison, 2016) [24]. This is due to the fragmented nature of the TESOL industry worldwide, the aggressive marketing of TESOL as a viable career choice for school leavers which has led to an influx of unqualified or partly qualified teachers and the confusion as to where TESOL actually belongs as a discipline. At some universities, both internationally and in South Africa, the TESOL department or the university-affiliated language school falls under the administration of the English department whereas at other universities, it is administered by the Linguistics or Applied Linguistics department. In other cases, it forms a separate 'remedial' or 'academic access' unit under the broad control of Humanities.

This is exacerbated by a general lack of support of TESOL teachers from the management of private language schools, serious concerns about the status of TESOL as a profession and the devaluing of the field due to the propensity of many private language schools to employ temporary teachers on short-term employment contracts. Chowdbury and Le Ha (2014) [25] and Neilsen (2014) [26] observe that TESOL is a mobile career with high rates of international movement and subsequent attrition and, as a result, large numbers of TESOL teachers enter and leave the profession every year. Thus, it becomes difficult to demand high standards of certification which results in low status and inferior rewards. Furthermore, Johnston (1999, p.38) [17] states that, "By the age of 45, a very small proportion of EFL teachers are left in full-time employment...For most teachers who have done their five or ten years at the coalface and have collected their qualifications, there is nowhere to go but sideways." Thus this 'downside' of TESOL lays the foundation for stressful working conditions.

\section{Literature Review: TESOL Teacher Stress}

There have been relatively few studies on the topic of stress among TESOL teachers. Several researchers have investigated job satisfaction among TESOL teachers and the results of these studies have shed some light on what TESOL teachers find stressful. Zare (2007) [27] conducted a case study of nineteen Iranian TESOL teachers and found that the teachers derived job satisfaction from their students' academic achievements and positive relationships with students, parents and supervisors. The teachers were, however, not satisfied with educational policies, lack of teaching resources and the lack of opportunities to advance their careers. Johnston (1997) [28] conducted a study based on life history interviews with seventeen TESOL teachers in post-communist Poland. He discovered that the teachers considered themselves to be underpaid and overworked and often endured difficult physical and psychological conditions. Most of the teachers held multiple jobs due to low wages and their life histories lacked a discourse of professionalism and had a sense of having a career over which the teachers had only a modicum of control. Pennington's (2015) [29] research supports this noting that the major sources of dissatisfaction lie in factors extrinsic to teaching such as low pay, job insecurity, poor working conditions, lack of status and few opportunities for 
professional development.

Karavas (2010) [30], in a study of the job satisfaction of Greek TESOL teachers, found that of 224 TESOL teachers surveyed, $60 \%$ were satisfied with the recognition they received from their community but less than half (48\%) were satisfied with their status as a TESOL teacher in their respective school. The teachers were most dissatisfied with issues relating to school structures and policy making, the ambivalent status of TESOL as a profession, low salaries and few opportunities for advancement. Furthermore, Karavas (2010, p.71) [30] posits that the student-teacher relationship is central in enhancing teacher satisfaction and when that relationship breaks down, "emotional exhaustion, a sense of futility and reduced personal accomplishment creeps into teachers working lives." According to Karavas (2010, p.71) [30], an "alarming number of teachers feel emotionally drained, stressed and even burnt out from their work."

Sellen (2007, p.20) [31], a TESOL teacher, describes her descent into stress and later into burnout saying "I became less patient. I tired of explaining the same grammar points over and over again. I tired of reading students' attempts at writing...I felt no remorse as I...coldly returned papers with poor grades and scant remarks about areas that needed improvement. I also secretly resented students showing up for office hours." She also maintains that "Teaching is hard work and language teaching is especially demanding." Sellen believes that stress is a taboo subject and many teachers are afraid of being judged negatively by their colleagues as admitting to feeling stressed and unable to cope "implies a weakness, a level of emotionality that has no place in the workplace" (Sellen, 2007, p.21) [31].

Around the world it is common practice for private language schools and universities to employ English language teachers at low salaries and on a series of part-time contracts which may be renewed course-to-course or yearly. Mullock (2009) [32], reports that $25 \%$ of the TESOL teachers interviewed during the course of her research on motivation and rewards among TESOL teachers in south-east Asia stated that if they had their lives over again they would not choose to work as TESOL teachers due to the low salaries. TESOL teachers may thus work at several schools on a contractual basis or hold a second job in the evenings or at weekends just to make ends meet. Consequently, they feel discouraged, frustrated and insecure which leads to feelings of stress.

Clandfield (2010) [33] maintains that TESOL teachers feel stressed by student apathy, discipline issues in the classroom, excessive testing imposed by administrators, lack of recognition and no possibility of an improvement in working conditions. Several teachers spoke of the 'ugly' side of TESOL characterised by poor working conditions, long working hours, a lack of job security and low salaries. In a study of emotions experienced by TESOL teachers in connection with their students, colleagues and work, Cowie (2011) [34] found that negative emotions were reported around classroom conditions, poor facilities, the perceived inequality between full and part-time teachers, a lack of support for teachers and few opportunities for collaborative development. Furthermore, teachers spoke of a deep-seated anger, resentment and frustration with the institutions in which they worked due to a lack of institutional support.

\section{Methodology}

\subsection{Participants}

The study consisted of semi-structured interviews conducted with forty TESOL teachers working at seven private language schools in Johannesburg. In-depth, semi-structured interviews were used in order to gather rich, thick descriptive data that explored which factors, both inside and outside the classroom, caused feelings of stress for TESOL teachers working at private language schools. The study was limited to English first-language TESOL teachers as TESOL teachers who are first-language speakers of other languages experience a range of different stressors associated with teaching English (Takahashi, 2014) [35]; TESOL teachers who held South African citizenship and were thus committed to work in South Africa for the long-term and those who had a minimum of two years TESOL teaching experience as these teachers would have had adequate experience in the field.

The semi-structured interviews took the form of an interview based on the questions of what caused the teachers' to feel stressed inside and outside the TESOL classroom. Each interview took between one to two hours and was recorded and later transcribed by the researcher.

\subsection{Data Analysis}

The data obtained from the semi-structured interviews was analysed by means of thematic analysis. The researcher followed the six phases of data analysis as suggested by Braun \& Clarke (2006, p.18-23) [36] and loosely based on the work of Attride-Stirling (2001, p.385-405) [37]. Phase one consisted of immersing oneself in the data in order to become familiar with the content. This immersion involved repeated active reading of the data accompanied by making notes and searching for meaning and patterns. Phase two involved generating initial codes from the data. These codes identified interesting features of the data and involved sorting the data into meaningful groups. Phase three entailed searching for themes within the coded data using mind maps and then investigating the relationships between codes, themes and different levels of themes such as main and sub-themes.

Phase four involved reviewing the themes so as to refine them, achieve coherence and find clear and identifiable distinctions between themes. In Phase five, the themes were organised into a coherent and internally consistent account with an accompanying narrative. The researcher conducted a detailed analysis for each theme and identified the story that each theme told. In addition, sub-themes were identified 
which were useful in giving structure to particularly large and complex themes and also for demonstrating the hierarchy of meaning within the data. Once the researcher had a set of fully worked out themes, the final analysis and writing-up of the data began which constituted phase six (Braun et al., 2006: 36).

\section{Findings}

The data derived from interviews with the forty participants yielded three major areas that resulted in stress for the teachers, namely the job of teaching, relationships at work and organisational and TESOL-related issues. Each of the three major themes consisted of various sub-themes discussed below. The sub-themes are accompanied by selected extracts from the interviews conducted with the TESOL teachers.

\subsection{Major theme 1: The job of teaching}

\subsubsection{Sub-theme A: Work Overload}

Teachers felt that teaching consumed most of their time to the detriment of family life and social activities. Anne ${ }^{\text {ii }}$ believed that lesson preparation and teaching consumed all of her time saying, "One of the reasons that I'll eventually leave teaching is because I want the time outside work to be my own." Nina agreed saying that, "Teaching is all-consuming. There is no time for a social life or hobbies." There seems to be more for teachers to do with less time to do it in. Thus there is a reduction in the quality of teaching as corners are cut to cover the syllabus and as the work intensifies, teachers become increasingly de-professionalised and de-skilled. This leads to feelings of being overwhelmed and to the experience of stress. Shaleeda described how she had become so "overwhelmed by administrative tasks such as lesson planning and reports" that she had little time to reflect on their purpose.

\subsubsection{Sub-theme B: Inadequate Training and Gaps in Subject Knowledge}

One of the main criticisms of the TESOL industry is the lack of standardised entry qualifications. In addition, there is increasing concern about whether the training, which varies from one week and one month-long TESOL certificates and diplomas to Bachelors, Honours and Masters level degrees, is adequate preparation for the actual teaching. Inadequate training can lead to low self-esteem and a sense that one lacks competence in the classroom. In TESOL teaching, novice teachers are often thrown in at the deep end and expected to teach classes without having undergone a period of observed teaching or mentoring. Lisa described how on her first day the head of department "threw a grammar book into my arms, patted me on the back and sent me on my way."

Furthermore, the teachers felt that they were expected to be competent grammarians yet most of the TESOL training courses they attended had not prepared them for grammar teaching. Nina related how in her TESOL course, grammar had not been covered and she "was just given a grammar book and told to go home and learn it." Rachel agreed saying, "My students are obsessed with grammar. I have been forced to re-learn the grammar of English as I go along in order to be a more effective teacher." As first language speakers of English acquire rather than 'learn' grammar, these teachers had to explicitly learn the grammar rules of English in order to be able to teach them. Thus this is a potentially stressful area for TESOL teachers.

\subsubsection{Sub-theme C: Time Pressure}

Most English courses in private language schools in South Africa are between six and seven weeks long per level. There is an expectation on the part of the students and the management of the school that teachers complete the prescribed course book.

Douglas described how "For the students, the book is their safety net. The minute you do work that is not in the book, they get uncomfortable." Anne agreed saying, "We tried using our own material but it was a disaster. The students pay a lot of money and they equate the book with a good course. If they get worksheets and no book then they think the course is rubbish." Nina felt that the courses were too short and "we hardly ever finish the course book. This causes a lot of unhappiness for the students. A text book designed for a year-long course means there is too much to be done in six weeks. Frankly, I can't cope."

Anne felt that it was not possible for students to improve their language skills significantly in a seven-week course saying, "The courses are too short. In my opinion, the schools run short courses so as to make maximum money. Sometimes I hardly manage to get through half of the course book in seven weeks. You can't just keep on moving forward when you can see your students don't understand."

\subsubsection{Sub-theme D: Student Behaviour}

Student behaviour is a major source of stress for TESOL teachers. A lot of time is wasted in the classroom while teachers attempt to manage disruptive students and regain control.

Rachel felt that her students could be difficult to control and that her teaching had become "reactive because you never know what you are going to find in the classroom. It is unnatural to have a class of twenty-five adults from different cultures, languages, nations and religions and expect one person to be able to manage them." She also commented that some students, while not disruptive, seemed to be "sleepwalking, irritatingly passive, sullen and disinterested" while Taylor felt that "the main discipline problems are persistent use of the first language, defiant students who are rowdy and distract others, and students who come to class unprepared or late."

The teachers expressed concern about students who were 
argumentative and aggressive in the classroom. Anne said that "In every group, there is at least one student who badgers you. They see the opportunity to 'question' the teacher. I can't help feeling as if it is a personal attack." As TESOL teachers are mainly employed on short-term contracts and are not unionised, it would be unlikely for a TESOL teacher to pursue the matter further. TESOL teachers are often reluctant to admit to student behavioural problems as they fear that it may reflect on their own professionalism and that they will not get support from the management of the school.

\subsection{Major Theme 2: Relationships at Work}

\subsubsection{Sub-theme A: Colleagues}

Several of the teachers described disagreeable relationships with colleagues as emotionally exhausting and felt that it led to increased isolation among colleagues.

There was considerable tension between teachers as a result of entry requirements into TESOL teaching. Many of the teachers raised concerns about the low entry requirements for the profession and the fact that a teacher with a Bachelor's degree and a TESOL qualification could earn the same salary as those with lesser qualifications. Lisa explained that "Salaries are the same for all the teachers. It doesn't matter if you have a Master's degree in TESOL and years of experience, you earn a similar salary to someone who has done a short TESOL course and who has limited teaching experience." It should be noted that the University of South Africa was the only university in South Africa to offer a Bachelor of Arts Honours degree specialising in TESOL. The degree was discontinued in 2011 as the student numbers never reached the minimum level of twenty students needed for the course to be viable. ${ }^{\mathrm{iii}}$ This is significant as it means that private language schools and the TESOL industry in general are not enforcing standards for entry to the profession. If this were the case then undergraduate and postgraduate degree programmes in TESOL would have sufficient student numbers.

Many of the teachers felt socially isolated from their colleagues. There had been limited collaboration on different projects but the teachers felt that this was somewhat forced by co-ordinators. According to Claire, a sense of isolation was due to the nature of the job. She explained that, "I see my colleagues briefly before classes start, at the tea break and then after class. The only time we sit down together is at the weekly meeting. I think we need to spend more time together as a group and share ideas. I find it stressful that there never seems to be any meaningful communication between us."

\subsubsection{Sub-theme B: Administrators}

Some of the teachers felt that administrative support staff lacked adequate training. According to Warren, the support staff at his school needed to learn "how to interact with foreign students. I think that they are impatient with the students and often rude." Claire agreed saying, "The office staff are there to help the students but I have seen them laughing behind the students' backs especially those who struggle with English. They act as if students are stupid purely because they don't speak English." Vicky maintained that she normally accompanied her students to the office as the support staff "speak at the students rather than to them. This makes me feel embarrassed and it is stressful because it is not part of my job yet I feel compelled to smooth the way for my students."

Many of the teachers recounted stressful experiences involving their interactions with support staff. These experiences mainly revolved around issues such as the allocation of classrooms and the availability of resource material and other supplies. Jonathan, who taught evening classes twice a week, mentioned how "Every so often I find the office locked and everyone gone. I can't make photocopies, get queries answered or get keys to other classrooms. It is very frustrating. You can't run evening classes and have no office support." Frankie echoed this saying, "I teach on Saturday mornings and at least once a month I find that someone has double-booked my classroom. So I have to stand there arguing with another teacher in front of my students. I wake up on Saturday mornings with a knot in my stomach."

\subsubsection{Sub-theme C: Management}

Most of the teachers interviewed commented on the prevalence of workplace bullying in language schools. Workplace bullying takes many forms and can include an unmanageable workload and unreasonable deadlines, humiliation and ridicule at work, having one's opinions and views ignored, being the victim of malicious gossip and being excluded from the group. Prolonged bullying is extremely stressful and can lead to anger, anxiety, depression, panic attacks and burnout. Some of the teachers felt that this was a direct result of the contractual nature of employment in the industry and the fact that there were more TESOL teachers than positions available thus a school could easily dismiss a group of teachers and replace them with a new group within a short period of time.

Rachel described how a colleague had been bullied because he had spoken up about poor working conditions. She said "Either you were seen to be supporting him or you were on the side of management. It poisoned the atmosphere of the school. Next thing we knew the school had not renewed his contract. It was a lesson to all of us. Shut up or ship out." Mark agreed saying, "It goes against the grain but you simply can't get involved in someone else's fight if you want to keep your job. There is a mind-set that teachers have to be 'told' what to do and micro-managed. In their eyes, it is not bullying, it is getting things done."

\subsection{Major Theme 3: Organisational and TESOL-related Issues}

\subsubsection{Sub-theme A: Working Conditions}

Most of the TESOL teachers interviewed felt that the 
physical working conditions at the various schools could be improved. Their concerns included the poor condition of the buildings and classrooms, the small size of the classrooms, temperature control in the classrooms as it tended to be either too hot in summer or too cold in winter and the general lack of space for teachers and students.

Rachel described her initial experience at her school thus, "We were in an old building that was being renovated. We had to teach with drilling, sawing and hammering all day. The worst thing was that the building had huge crickets everywhere, crawling around the class, climbing into your bag or dropping out of the ceiling onto your desk. I don't know how I survived it."

Several of the teachers felt that the classrooms at the various schools were small and cramped. Fern commented that, "I teach fifteen students in a classroom big enough for ten. My students sit shoulder to shoulder and there isn't enough space to move around. We don't have space to play games and do physical activities." Lisa related a story of how, at her school, there were often not enough classrooms with teachers having to teach wherever they could find a space with some "teaching in corridors, out on the sports fields, in a corner of the library or simply poaching an empty classroom and hoping no-one will come along and claim it."

All of the teachers felt that the practice of short-term contract employment without benefits such as medical aid and pension was very stressful. Furthermore, teachers felt that contractual employment led to a lack of trust between teachers and the school leadership and a lack of commitment and loyalty on the part of the teachers. Joanne noted that "I know of at least three teachers who have given up on a career in TESOL because of the lack of secure, permanent employment." Lisa echoed this sentiment saying, "All the teachers at our school are on fixed-term contracts of between one to three years. You can never assume that your contract will be renewed. The result is that you can't make any long-term, major purchases like a car or a house."

\subsubsection{Sub-theme B: Lack of Teaching Resources}

Due to financial constraints, private language schools often do not have adequate resources. Many TESOL teachers, therefore, have to make their own resources or purchase the resources themselves.

Lisa described how, "We have very few resources to relieve the monotony of the course book. I download and print worksheets at my own cost as we are not allowed to make lots of copies at work. Actually, they want us to use only the course book. It is quite stressful for us because we always have to think of cheap ways to make our lessons exciting." Taylor agreed saying, "We have been asking for extra resources for ages. Eventually we brought our own board games and magazines from home. We also buy newspapers for the more advanced students to read."

Many of the teachers felt that the sharing of resources was stressful. Anne described how some of the teachers are careless saying, "Some of the books have spills on them and their covers are bent and some of the games are missing playing pieces. I find this so disrespectful." Joanne agreed commenting, "The sharing of resource material is very stressful. The thing you want is always being used by someone else at precisely the time that you want it, the books get torn and dirty, the games fall apart. I have actually stopped using the resources here. I have bought my own which I use when I need to and then take home with me again."

\subsubsection{Sub-theme C: Shared spaces}

The use of communal classrooms and a lack of space for teachers to prepare, plan, think and mark is a problem particular to TESOL and is symptomatic of the marginalisation of the field and those who work in it. Lisa described how, "At one school I worked at, my students and I spent the beginning of every day roaming the corridors looking for an empty classroom or at worst, a quiet corner." Rex said that in the seven years that he had taught TESOL, he had not yet experienced "the luxury of a classroom of my own." Shaleeda told how, over the years, she had "had held classes in storage rooms, corridors, converted cupboards and under stairwells, in noisy canteens, in libraries and in small, overcrowded classrooms." Perhaps these inadequate instructional spaces are representative of how TESOL programmes are generally regarded.

Most of the teachers interviewed not only worked in shared classrooms but also had to share office space which was a significant source of stress. Sara described how at her current school, "There are eight TESOL teachers and we share a tiny office. There is one computer shared by eight of us. It is frustrating. There is never enough space. It is exhausting to be in that room. I can't work in there so I do all my admin and reports from home in the evenings and over the weekend. This makes me feel as if I'm constantly working."

\subsubsection{Sub-theme D: Lack of Professional Development and Career Advancement}

Many of the teachers interviewed felt that most of the language schools did not have a clear understanding of how to implement a professional development programme and were reluctant to develop such a programme due to financial and time constraints.

Lisa maintained that, "As teachers we can do a lot on our own but we also need the support of the school. There is no point in developing materials that are not used, we can't afford to become members of most professional organisations, and doing research and writing for publications all takes time that we don't have." Mark agreed saying, "We have had a few workshops and we have a small library but when it comes to funding studies or research or an overseas trip to attend a conference, it is not going to happen."

The lack of professional development for TESOL teachers is accompanied by minimal career progression. Lisa 
described the situation thus, "There aren't many opportunities for advancement so when something comes up, everyone applies. Then they employ an external person. It is stressful and makes us feel like there is no way of moving forward." She added that, "I don't think there is much of a future in South Africa for TESOL teachers because the schools won't pay the kind of salaries that graduates expect. So what is the point of studying further in TESOL? On top of that, there is nowhere to go, you start as a teacher and that's where you stay."

All of the teachers interviewed felt that the lack of career opportunities for TESOL teachers in South Africa was stressful. Lisa explained, "You find yourself with an MA in TESOL, years of teaching experience and a huge amount of knowledge but no work. So you end up at a private language school on a contract, earning the same as someone twenty years younger than you with no qualifications." Rex agreed saying, "The industry is small and the opportunities are few. This creates stress. The schools don't want over-qualified teachers, people who question the status quo ... so if you are outspoken and too qualified, you may find yourself out of a job quickly!"

\section{Discussion}

The job of teaching and its related tasks was a major contributor to feelings of being stressed. The teachers felt that they were overloaded with work and under significant time pressure to complete various tasks. They expressed concern about the lack of work-life balance in TESOL teaching, the amount of preparation time required for classes and the fact that they were consequently finding teaching to be boring and tedious. In addition, many of the teachers felt that they had received inadequate training on the various TESOL courses they had attended and that there were significant gaps in their knowledge particularly in the area of English grammar.

They also expressed concern about the lack of standardised entry qualifications to the profession and the proliferation of unqualified and under-qualified teachers in the field. Student behaviour was also a major sub-theme with the teachers saying that, in general, student behaviour was becoming worse and their ability to manage difficult students was limited by disinterested school leadership and the tenuous nature of their employment.

Relationships and interactions with others at work were perceived to be a major contributor to feelings of stress. The teachers felt that generally their collegial relationships were negative and unsatisfactory. They described the overriding teacher culture as overwhelmingly toxic and characterised by competitiveness, gossip and hostility. The administrative support staff, whose function was to assist the teachers, was generally viewed as unsupportive. In terms of relationships with the management of the various schools, the teachers believed that they had been victims of workplace bullying or had witnessed bullying incidents directed at colleagues.
They also expressed concern about the general lack of support from management, the manner in which teacher observations were conducted and the constant threats of cost-cutting measures.

The final major stressor was that of organisational and TESOL-related issues. Teachers felt stressed by their working conditions which included the poor state of the buildings and classrooms at many of the private language schools. In addition, almost all of the TESOL teachers were on short-term employment contracts and none of them felt that they earned market-related salaries. Furthermore, the schools paid all teachers within the same salary range thus there was no incentive to improve qualifications. Teachers who held post-graduate degrees felt resentful as they received the same salary as those who had completed entry level TESOL courses.

Teachers also mentioned the lack of adequate teaching resources, the fact that many of the schools did not have the money to purchase resources and that there were problems surrounding the abuse and sharing of teaching resources. Sharing space with colleagues was also cited as being a source of stress. This included lack of access to communal classrooms, not having one's own classroom, having to move to different classrooms and the challenges of sharing office space. All of the teachers expressed discontent regarding their lack of professional development and career advancement.

While stress negatively impacts on teachers' performance in relation to their students and colleagues it also affects their own emotional, mental and physical well-being. The consequences are even greater for TESOL teachers' who work in an industry that marginalises them and regards them as dispensable. TESOL teachers who suffer from ongoing stress can be easily sidelined and replaced. Unlike English teachers who work in the primary and secondary school system as permanent employees, TESOL teachers do not have the option of being placed on long leave in order to recover.

The results of the study reveal that TESOL teachers working at private language schools in South Africa experience a considerable amount of stress. As language teaching is a profession conducted in front of people and for the benefit of people, the consequences of stress are frustrating for both the TESOL teachers concerned and their students. Stress has a negative effect on teachers, schools and students. These effects may include a lack of enthusiasm and motivation, increased absenteeism, a decline in classroom performance, poor interpersonal relationships with students and colleagues, lower tolerance for classroom disruptions, inadequate preparation for classes, and becoming increasingly dogmatic and resistant to change.

\section{Conclusions}

There is a scarcity of research on TESOL teachers and their emotions, experiences and thoughts. The realities of 
TESOL teachers' lives remain unchartered territory. While there are many satisfactions inherent in the job, the dissatisfactions are self-evident. These include a profession that lacks professional status, is riddled with ambiguities and confusion and is characterised by work overload, unfair treatment, low salaries and job insecurity. Private language schools, unfortunately, are complicit in this rather bleak picture of the world of TESOL as they continue to place profits first, employ unqualified and under-qualified teachers and offer poor working conditions and unattractive salary packages. In South Africa private language schools are part of a lucrative albeit intensely competitive industry but tend to remain independent operators who make up the rules as they go along. The TESOL teachers are thus viewed as an expendable resource.

The management of private language schools need to become more aware of the major stressors affecting their teachers. It follows then that schools can also determine what will lead to a reduction in stress levels among teachers. This may include reducing teaching workloads, improving working conditions, employing teachers with the correct TESOL qualifications for the job, recognising teachers' achievements so as to increase teaching efficacy and a focus on increasing teachers' self-esteem and coping strategies. Furthermore, it is important that the management of schools become aware of changes to organisational factors which may reduce the experience of stress. These include providing support networks for teachers, formal career planning and advancement, allowing teachers to be part of major decisions, providing job security, the provision of adequate physical facilities and clear job expectations.

TESOL teaching does not and cannot occur in isolation and effective teaching takes place with the assistance of others in a supportive atmosphere. TESOL teachers must, therefore, be increasingly proactive and attempt to build positive relationships with colleagues, administrators and managers. Even if schools are unwilling to provide support, there is nothing preventing teachers from forming their own networks of professional colleagues, either within their schools or by means of a virtual network which transcends borders.

This research study shows that the TESOL industry in South Africa suffers from similar challenges as the TESOL industry in other parts of the world. In South Africa, working in TESOL is still widely perceived as a temporary form of employment for students filling a gap year, for those who want only part-time employment, for those who are not yet sure what they want to do with their lives and for those who wish to gain some teaching experience before travelling overseas. This perception is intensified by the fact that private language schools rarely offer permanent, full-time employment with benefits and market-related salaries. Employment is mainly contract-based and dependent on student numbers. Thus, as a result many teachers leave the local and international TESOL industry every year. It is undeniable that teacher attrition drains financial resources and diminishes the quality of education. It is also unfortunate that talented teachers leave the TESOL profession exhausted from the work of teaching and the constant stress created by the conditions of TESOL teaching. What is even more unfortunate is the myriad of students who lose the opportunity to learn from them.

\section{REFERENCES}

[1] Golombek, P. and Doran, M. (2014). Unifying cognition, emotion and activity in language teacher professional development. Teaching and Teacher Education, 39, 102-111.

[2] Horwitz, E.K. (2012). Becoming a language teacher: a practical guide to second language learning and teaching. Boston, USA: Pearson Education.

[3] Larrivee, B. (2012). Cultivating Teacher Renewal: Guarding Against Stress and Burnout. Plymouth, UK: Rowman and Littlefield Publishers.

[4] Kyriacou, C. (2001). Teacher Stress: Directions for future research. Educational Review, 53 (1), 27-35.

[5] Manuel, J. (2003). 'Such are the ambitions of youth': Exploring issues of retention and attrition of early career teachers in New South Wales. Asia-Pacific Journal of Education, 31 (2), 125-138.

[6] Friesen, D., Prokop, C.M. \& Sarros, J.C. (1988). Why teachers burn out. Educational Research Quarterly, 12 (3), 13-34.

[7] Maslach, C. \& Leiter, M.P. (1999). Teacher Burnout: A Research Agenda. In Vandenberghe, R. \& Huberman, M. (Eds.), Understanding and preventing teacher burnout: A sourcebook of international research and practice. Cambridge, UK: Cambridge University Press.

[8] Chang, M. (2009). An Appraisal Perspective of Teacher Burnout: Examining the Emotional Work of Teachers. Educational Psychology Review, 21, 193-218.

[9] Prilleltensky, I., Neff, M. and Bessell, A. (2016). Teacher Stress: What it is, Why it's important, How it can be alleviated. Theory into Practice, 56 (2), 1-18.

[10] Van Tonder, C. L. \& Williams, C. (2009). Exploring the origins of burnout among secondary educators. SA Journal of Industrial Psychology, 35 (1), 204-218.

[11] Barkhuizen, N., Rothmann, S., \& Tytherleigh, M.Y. (2008). Occupational stress of academic staff in South African higher education institutions. South African Journal of Psychology, 38, 321-36.

[12] Barkhuizen, N., Rothmann, S., \& van de Vijver, F.J.R. (2014). Burnout and Work Engagement of Academics in Higher Education Institutions: Effects of Dispositional Optimism. Stress and Health, 30 (4), 322-332.

[13] Monareng, S. (2006). Stress levels among government secondary school teachers in a semirural area of KwaZulu-Natal. Unpublished master's thesis, University of KwaZulu-Natal, South Africa.

[14] Peltzer, K., Shisana, O., Zuma, K., Van Wyk, B. \& 
Zungu-Dirwayi, N. (2009). Job stress, job satisfaction and stress-related illnesses among South African educators. Stress and Health, 25, 247-257.

[15] Olivier, M.A.J. \& Venter, D.J.L. (2003). The extent and causes of stress in teachers in the George region, South African Journal of Education, 23 (3), 186-192.

[16] Shin, J.C. and Jung, J. (2014). Academics job satisfaction and job stress across countries in the changing academic environments. Higher Education, 67 (5), 603-620.

[17] Johnston, B. (1997). Do EFL Teachers Have Careers? TESOL Quarterly, 31 (4), 681-712.

[18] Griffiths, C. (2012). Focus on the teacher. ELT Journal, 66 (4), 468-476.

[19] Simon-Maeda, A. (2004). The Complex Construction of Professional Identities: Female EFL Educators in Japan Speak Out. TESOL Quarterly, 38 (3), 405-436.

[20] Kassagby, O.,Boraie, D., \& Schmidt, R. (2001). Values, rewards and job satisfactions in ESL/EFL. In Dornyei, Z. \& Schmidt, R. (Eds.), Motivation and second language acquisition. Honolulu: HI, University of Hawaii, Second Language Teaching and Curriculum Centre, Technical Report $23,213-237$.

[21] Kim, T. and Kim, Y. (2015). Initial Career Motives and Demotivation in Teaching English as a Foreign Language: Cases of Korean EFL Teachers. Porta Linguarum, 24, 77-92.

[22] Walker, J. (2014). ESOL as Business: Time for the Market-Oriented Teacher? TESOL Journal, 5 (1), 159-171.

[23] Sun, Y. (2010). Standards, Equity and Advocacy: Employment Conditions of ESOL Teachers in Adult Basic Education and Literacy Systems. TESOL Journal, 1 (1), 142-158.

[24] Crandall, J. and Christison, M. (2016). (Eds). Teacher Education and Professional Development in TESOL. New York, USA: Taylor and Francis.

[25] Chowdbury, R. and Le Ha, P. (2014). Desiring TESOL and International Education: Market Abuse and Exploitation. Bristol, UK: Multilingual Matters.

[26] Neilsen, R. Global Nomads: TESOL Teachers in a Shifting World. In Arber, R., Blackmore, J. and Vongalis-Macrow, A.
(2014). Mobile Teachers, Teacher Identity and International Schooling. Rotterdam, The Netherlands: Sense Publishers.

[27] Zare, S. (2007). Are EFL Teachers Satisfied with their job? A case study of Iranian EFL teachers. Pan-Pacific Association of Applied Linguistics, 11 (1), 69-77.

[28] Johnston, B. (1999). The Expatriate Teacher as a Postmodern Paladin. Research in the Teaching of English, 34 (2), 255-280.

[29] Pennington, M.C. Teacher Identity in TESOL: A Frames Perspective. In Cheung, Y.L., Said, S.B., and Kwanghyun, P. (Eds). (2015). Advances and Current Trends in Language Teacher Identity Research. New York, USA: Routledge.

[30] Karavas, E. (2010). How Satisfied are Greek EFL Teachers with their Work? Investigating the Motivation and Job Satisfaction Levels of Greek EFL Teachers. Porta Linguarum, 14, 59-78.

[31] Sellen, J. (2007). Both Ends Burning. Essential Teacher, 4 (1), 20-22. Retrieved from:http://www.tesol.org/docs/pdf/12826. pdf?sfvrsn=2

[32] Mullock, B. (2009). Motivations and rewards in teaching English overseas: A portrait of expatriate TEFL teachers in South-East Asia. Prospect, 24 (2), 1-16.

[33] Clandfield, L. (2010). Are you suffering from burnout? E-Bulletin TESOL Macedonia Thrace Northern Greece, 32, 12-14. Retrieved from: http://www.tesolmacthrace.org/en/ebulletins

[34] Cowie, N. (2011). Emotions that experienced English as a Foreign Language (EFL) teachers feel about their students, their colleagues and their work. Teaching and Teacher Education, 27, 235-242.

[35] Takahashi, H. (2014). Nonnative English-speaking Teacher's Self-perceived Language Proficiency Levels, Anxieties and Learning Strategies. International Journal of Christianity and English Language Teaching, 1, 24-44.

[36] Braun, V. \& Clarke, V. (2006). Using thematic analysis in psychology. Qualitative Research in Psychology, 3 (2), 77-101.

[37] Attride-Stirling, J. (2001). Thematic networks: an analytic tool for qualitative research. Qualitative Research, 1, 385-405

i To be permitted to work in the South African primary and secondary school system, one has to either hold an undergraduate degree with appropriate teaching subjects and a one-year Postgraduate Certificate in Education (PGCE) or hold a four-year Bachelor of Education degree. All teachers working in the South African school system need to be registered with the South African Council of Educators (SACE).

ii The names of all participants are confidential thus pseudonyms have been used.

iii Information supplied by Professor Brenda Spencer, English Department, University of South Africa. 